\title{
Chapter 4 \\ Case Study of a Private Sector Firm in Indonesia
}

\begin{abstract}
Key issues, challenges, concerns, and prospects arising from a case study of the Astra Manufacturing Polytechnic in Jakarta, Indonesia, are presented, analysed, and discussed. A descriptive portrait is provided of the case study firm. Steps in the accreditation process are explained and discussed, as are partnership arrangements between Astra Manufacturing Polytechnic and government, including on-and off-the-job training activities, and the Meister programme for existing workers. Key lessons learnt from this case study are presented to provide a role model for the effective greening of business forms in Indonesia and as a guide for business firms throughout the region.
\end{abstract}

Keywords Private sector firms - Informal and rural sectors • Integration of green learning opportunities $\cdot$ On and off-the-job training opportunities $\cdot$ Meister program

\section{By Belinda Smith, International private sector skills specialist}

Successful partnerships between private sector industries and education and training institutions are needed to implement skills development for green jobs

\section{Introduction}

This case study was conducted at the Astra Manufacturing Polytechnic in Jakarta, Indonesia. It is an example of the successful implementation of skills development for green jobs. Data were collected using a variety of methods, including a site visit to make nonparticipant observations of the facilities available to students and teachers working at the polytechnic.

Several key issues may be identified as arising from this case study. 
Courses take 3 years full-time to complete and graduating students achieve a diploma level III as a junior engineer. Short courses are also provided. Astra International provides $35 \%$ fully funded scholarships, and the other $65 \%$ heavily subsidized. Seventy percent of graduates get jobs within Astra International and $12 \%$ in other companies. Eighteen percent continue their studies at higher levels, while some start their own businesses.

Although there are no special programs for green skills, each subject has an integrated approach. Students learn to comply with environmental regulations and standards. All teachers have previously worked in factories and therefore have the required high-level skills to teach courses and pass on their knowledge of green practices in workshop learning activities. Programs consist of $65 \%$ practical skills development and 35\% theory. The competency standards of programs are aligned to job opportunities within Astra International. During the final year of courses, generic skills and green skills such as waste management and energy and water efficiency are taught. The workplace component of the polytechnic model is not treated as a separate adjunct to the learning process. Learning through participation in work that is inseparable from classroom and workshop training is emphasized. The success of this approach is indicated by the high number $(69 \%)$ of graduates who are considered immediately productive (work-ready).

Astra has developed initiatives to support local communities and government vocational secondary schools (VSSs) despite knowing that the delivery of TVET in schools is more costly than general academic subjects. Teachers from these schools are trained for 2-3 months, spending time, for example, in factories gaining knowledge about new standards, processes, and policies that are subsequently passed onto the students attending the courses. A wide gap has been found between the basic knowledge, skills, and abilities of graduates from urban areas to those from rural and remote areas. In addition, for graduates from VSSs, finding a job is difficult due to the lack of equipment and the academic nature of the training.

This case study demonstrates a successful partnership between the private sector and education and training institutions to implement skills development for green jobs.

Established in 1995 as the Federal Technic Academy, the Astra Manufacturing Polytechnic changed its name in 1999 under the sponsorship of Astra International, one of Indonesia's largest conglomerates. Most of the company's operations are focused on the Indonesian market. The Astra group has 192,895 employees in 187 affiliated companies and nine foundations with 6304 employees. The company is the largest automotive distributor and producer in Indonesia, partnering with Japanese vehicle manufacturers such as Toyota, Daihatsu, Honda, and Isuzu. Astra International has six core businesses: automotive, financial services (mainly to finance automobile purchases), heavy equipment, agribusiness, information technology (IT), and infrastructure. Automotive manufacturing and distribution is the largest division. Astra Manufacturing Polytechnic is a technical institute in the 
suburbs of Jakarta, based within the Astra vehicle manufacturing compound. Green skills are incorporated across subjects in the curriculum with a focus on energy efficiency, waste reduction, liquid and solid waste management and disposal, recycling, water efficiency, and the reduction of chemical usage covered under the relevant areas in the training programs.

The polytechnic, also known as Polman Astra, is fully funded by the company through the Astra Bina Ilmu Foundation and is accredited as a polytechnic by MoEC. It conducts programs under five specializations

Astra Manufacturing Polytechnic at
a glance
Company-funded, government-
accredited
Situated in the company factory
compound
82\% graduate employment
18\% graduates university
Strengthening six government
vocational high schools by training
equipment
65\% practical skills development
Integrated green skills development
670 students

- Mechanical Engineering, established in 1995 with Akademi Teknik Mesin Industri (ATMI) in Solo, a Jesuit polytechnic university;

- Production Engineering and Manufacturing Process, commenced in 1996 in cooperation with the Department of Mechanical Engineering at the Bandung Institute of Technology (ITB), a highly regarded Indonesian university;

- Information Systems, started in 1999 in cooperation with the Department of Information Technology, also at ITB; 
- Automotive Engineering, established in 2003 in cooperation with Astra Automotive Group and ITB; and

- Mechatronics, ${ }^{1}$ commenced in 2005 , internally developed based on existing programs.

These specializations highlight the tradition of partnerships that Astra Manufacturing Polytechnic has established over the years. Several of these partnerships are ongoing. ATMI in Solo is the oldest and most established teaching factory in Indonesia with the best tool-making program in the country. The two training institutions work together to identify ways to improve the image of TVET in Indonesia. ATMI, Astra Manufacturing Polytechnic, and Bandung Manufacturing Polytechnic hold their own skills competition to improve student skills. The three organizations have different strengths from which each can benefit. ATMI has the most established teaching reputation; Astra Manufacturing Polytechnic has the industry linkages; and Bandung Manufacturing Polytechnic has strong linkages with the government. For example, while ATMI does not have strong industry linkages, it has alumni throughout Indonesia, many of whom are in senior positions and who employ graduates from ATMI and the other two institutions. If one of the three organizations has an excess of very good students applying for its courses, it will refer them to the other two training institutions. The institutions also support each other to improve their internal systems for training by sharing approaches and how to improve the model of TVET being delivered. They also share some of their training courses.

Astra Manufacturing Polytechnic is still developing and improving internal education systems. This is a problematic process, and different approaches are required. Astra Manufacturing Polytechnic first adopted a Swiss and German educational approach that has since been influenced by the more recent requirements of the Indonesian TVET system, which is influenced by Australian competency standards. This is overlaid with the Astra management system based on a Japanese approach. Sometimes Australian competency and Japanese standards have been problematic in implementation. This has resulted in reviewing and changing internal education systems to accommodate the best of each group of standards where possible.

The polytechnic sits organizationally under the Astra Bina Ilmu Foundation in the Astra Group. The foundation focuses on professional education in the field of technology, particularly in automotive and natural resources. Scholarships are provided to employees, polytechnic teachers, and instructors for associate, undergraduate, and degree programs.

Indonesian polytechnics were created in the 1980s and are usually linked to universities. Students are eligible for entry after successfully completing 12 years of education and completion of the Ujian Masuk Politeknik entrance examination. Polytechnics provide D II (diploma level 2) and D III level programs, which usually

\footnotetext{
${ }^{1}$ Mechatronics is a design process that includes a combination of mechanical engineering, electrical engineering, control engineering, and computer engineering.
} 
involve 3 years of full-time study with pathways for graduates to continue on to higher education. Astra Manufacturing Polytechnic provides certification mainly at the D III level, which involves 3 years of full-time study plus 1 year of on-the-job training. Astra Manufacturing Polytechnic also provides short courses. To become an accredited polytechnic, the Astra Group sought accreditation through the National Accreditation Board for Higher Education (BAN-PT), which is under MoEC.

The accreditation process consists of the following steps:

(i) The institution conducts a self-evaluation and draws up a report.

(ii) Two or three assessors conduct a desk evaluation.

(iii) Accreditors conduct a site visit.

(iv) The assessors submit their report to the board of the BAN-PT for a final decision.

(v) Stakeholders are informed of the result of the accreditation.

(vi) Accreditors issue the accreditation certificate with recommendations for further development and program improvement.

(vii) The accreditation process is repeated every 5 years.

Along with the accreditation process, MoEC has education standards incorporating curriculum, competence, administration, financing, equipment, teaching staff, assessment standards, and minimum formal qualification levels for teaching staff. The commitment to maintaining and documenting the attainment of standards represents an additional effort to usual staff development activities. It also displays Astra International's commitment to provide formal recognition and access to educational pathways for their workforce. Astra Manufacturing Polytechnic considers the accreditation process and accompanying educational standards as a minimum set to be further reinforced with ISO quality and environmental standards. Both the students and the company believe the Astra certification is more beneficial and influential than government qualifications.

Demand for course places among prospective students is high, with an average ratio of 1:17. Subsidized students pay Rp12 million, while the actual course costs are Rp100 million. Seventy percent of graduates get jobs in Astra International; $12 \%$ in other companies; $18 \%$ continue their studies at higher levels; and some start their own businesses.

To gain entry into an Astra Manufacturing Polytechnic program, students need to take a series of psychometric tests. The tests do not emphasize academic ability. In addition to identifying potential graduates, these tests allow students disadvantaged by poorer schooling to compete with students from West Java. Students from East and West Java have a large gap in terms of academic performance. The quality of graduates generally declines from Jakarta in a radiating circle. ${ }^{2}$ Astra Manufacturing Polytechnic is conscious of ensuring that they do not just recruit students from Jakarta and is working to ensure that students from remote areas are

\footnotetext{
${ }^{2}$ Information from interview discussions.
} 
Table 1 Applicants and total intake, 2009-2012

\begin{tabular}{l|r|r|r|r}
\hline Applicants & 2009 & 2010 & 2011 & 2012 \\
\hline $\begin{array}{l}\text { Total number of } \\
\text { applicants }\end{array}$ & 1153 & 1939 & 2006 & 3995 \\
\hline Scholarship applicants & 240 & 1028 & 1076 & 2916 \\
\hline Regular applicants & 913 & 911 & 930 & 1079 \\
\hline Total intakes & 233 & 237 & 229 & 231 \\
\hline
\end{tabular}

Source Official records

able to enroll. The polytechnic provides dormitories for students from remote areas and sometimes offers a matriculation program, yet it is still difficult for the students from the east to attain the same level as students from West Java (Table 1).

Astra certifies the student and acknowledges the factory-related specialized skill area of the student and his or her final project. The polytechnic does not undertake an advertising campaign to attract students, but consults with government TVET institutions and their factories. Astra Manufacturing Polytechnic has undertaken small labor market studies, but the training programs are essentially aligned to the demands of the various companies in the Astra Group.

In addition to the mandatory subjects of civics, religion, and state ideology required by MoEC, the Astra Group of companies develops the polytechnic curriculum and informs MoEC of its endorsement by industry. From the Astra Manufacturing Polytechnic viewpoint, the industry endorsement is particularly important, more so than a government endorsement, as recognition of student competency arises from the industry.

\section{Integration of Green Learning Opportunities}

Astra International is working toward becoming a green company and follows a number of policies to support this, including a green strategy, green process, green product, and green employee approach. The Astra Group wants to comply with all relevant environmental regulations, both national and international. These are incorporated into the Astra Manufacturing Polytechnic training programs and internships.

There is no special program for green skills. Each subject has an integrated approach to green skills, so as the students learn a set of technical skills, they are also learning to comply with environmental regulations and standards as well as the Astra Group's green policies. Since teachers come from the factories, they integrate green practices into the workshop learning activities. Astra Manufacturing Polytechnic supports the company's green policies, and the company practitioners provide insights to the teachers on new environmental requirements. The teachers then pass on this knowledge to the students. Green skills are incorporated across subjects in the curriculum in areas such as energy efficiency, waste reduction, liquid and solid waste management and disposal, recycling, water efficiency, and 
reduction of chemical usage. These are covered under the relevant areas in the training programs.

Additionally, many of the final improvement projects deal with ways to lessen the Astra Group's factories' impacts on the environment. In addition to an air pollution project, students have undertaken projects to reduce and manage oil wastage, which have led to changes being implemented permanently within the factory. Another project identified ways to increase material efficiency in the production process. This also led to changes on the factory floor. Other projects have included reducing waste, increasing energy efficiency, and improving the factories' cleaner production programs. There are 224 projects per year, many concerning environmental improvements. These environmental process improvements are implemented within the Astra Manufacturing Polytechnic training programs, ensuring that students are up-to-date with current work practices.

\section{Partnership Between Astra Manufacturing Polytechnic and Government VSSs for CNG Mechanics}

The MoEC Directorate General of Higher Education, which has a vocational schools unit, identified six schools with limited VSS capacity to participate in the Astra Manufacturing Polytechnic program, on the latter's request. The technical and training support is free to the VSSs and to the teachers receiving the training.

MoEC provided the VSSs with CNG machines in 2015, but only a few teachers were trained on the use of the equipment. Astra Manufacturing Polytechnic provided 3-days training to one or two teachers from each of the schools on using the CNG equipment. The teachers often send the polytechnic a proposal for additional training, and Astra Manufacturing Polytechnic provides further training if feasible. Astra Manufacturing Polytechnic has a memorandum of understanding with the schools to provide 2-4 training programs of varying length and content per year over 3 years.

Astra Manufacturing Polytechnic does not receive funding from the government for this program. MoEC has a similar program wherein polytechnics are requested to provide professional development to vocational teachers from vocational schools of a certain region. Astra Manufacturing Polytechnic considers its program to be complementary to MoEC's program and has extended it to create master schools. Schools located near the master school are invited to attend training, which is organized and implemented by Astra Manufacturing Polytechnic. The six VSSs identified by MoEC may become master schools to support other VSSs in improving their quality. So far, one master school has been established, and others outside Jakarta are being identified. Master schools will be chosen based on a long-term relationship with the polytechnic, the school culture, and teachers' abilities. 
Successful implementation of TVET leading to meaningful outcomes for graduates poses a number of complex issues within a school environment. Some of these issues include teachers not having the skills and experience in the vocational areas where they provide skills development; the additional cost of equipment and facilities; and finally, access to resources so that students can practice and develop their competence. An ADB report ${ }^{3}$ has identified that delivering TVET in schools is more costly than delivering general academic subjects. Astra Manufacturing Polytechnic has developed an initiative to support government VSSs despite the costs.

Astra Manufacturing Polytechnic formed the Centre for Vocational Education Development in 2011 to help government VSSs improve the quality and relevance of their student graduate outcomes. VSSs face challenges in preparing students for work. In most instances, the teachers have never worked in the industry for which they are preparing their students. It is very difficult for graduates from VSSs to find jobs, ${ }^{4}$ due partly to the academic nature of the training and partly to lack of equipment. There is also a wide gap between the basic knowledge, skills, and abilities of students graduating from urban areas and those from rural and remote areas. This is further compounded by the East-West divide and the public-private school divide. One reason Astra Manufacturing Polytechnic decided to establish the Centre for Vocational Education Development is to redress the gap between students from different backgrounds. The vocational part of the VSS program is restricted to approximately $25 \%$ of the curriculum. This figure does not include mathematics, sciences, and English language, which are covered under the stipulated general education component. ${ }^{5}$

There is a major difference between general education foundation skills that might be technical in nature and the occupational competency standards in TVET, which are all about skills development within a workplace context (Smith 2012). Teaching general education technical skills is a common and traditional approach where education is contextualized to the world of work largely through incorporating narrow technical content into the curriculum, e.g., IT subjects or drafting skills where students learn to use perspective. The traditional education approach contextualizes technical skills in an educational environment. TVET demands skills that are contextualized in workplace conditions (deadlines, specifications, quality, etc.) and provide recognition for being able to perform that group of occupational skills to a particular identified industry standard. To develop occupational competence, students learn and practice applying vocational skills and knowledge in workplace contexts, under workplace conditions, including working with customers, working to a deadline and within a budget, and working under supervision. This critical change in emphasis requires a cultural shift within schools that

\footnotetext{
${ }^{3}$ ADB (2009). Education in Focus. Good Practice in Technical, Vocational Education and Training. Manila: ADB.

${ }^{4}$ www.unevoc.unesco.org/tvetipedia.0.html?tx_drwiki_pi1[keyword]=Indonesia.

${ }^{5}$ See Footnote 3 in Chap. 2.
} 
recognizes industry relevance as one of the key indicators of quality in TVET programs. The Astra Polman Centre for Vocational Education Development program assists in either facilitating or bridging this cultural shift.

The programs conducted by the Centre for Vocational Education Development provide curriculum and learning resources and offer technical assistance and teacher training in soft and technical skills. They provide a range of courses and activities for vocational secondary high school teachers. The training duration is generally 2-3 months depending on the program content, with some lasting one semester. Most training depends on what the teachers require. They are not set programs and vary according to the teachers' needs. Certain programs require the vocational school teachers to attend training at the polytechnic, while others bring polytechnic staff to train the teachers in their work environment.

Training is provided across a range of technical areas in areas such as automotive, quality control facilitation, pedagogy, and soft skills. They aim to improve the teaching and learning processes within VSSs. Sometimes the training is very basic, such as teaching teachers how to use CNG equipment. Teachers from outside Jakarta will stay for 3 weeks and attend training at Astra Manufacturing Polytechnic from 7:30 in the morning until 4:30 in the afternoon. The teachers will attend training in the classrooms and workshops, and shadow some of the polytechnic teachers in the workshops while they are teaching. During their time at Astra Manufacturing Polytechnic, the VSS teachers visit factories and observe how skills are applied and the contextual issues considered important, helping the teachers to appreciate the importance of production processes combined with technical skills.

\section{Harmonization of On- and Off-the-Job Training Activities}

Astra Manufacturing Polytechnic is situated on the grounds of the Astra International main company compound. The compound contains the Astra International head office, the automotive manufacturing factories, and the distribution center. The training approach is completely integrated with the workplace at all stages of the learning process, not relying on an up-front or back-end model of training and workplace exposure. The teachers at the polytechnic originate primarily from industry and return to the workplace on a regular basis depending on the workplace schedules. If they do not come from industry, they participate in regular workplace training similar to an apprenticeship training program. The teachers who teach the practical skills are from the factories. Some teachers work 4 days a week at one of the factories and teach 1 day a week in the polytechnic. These part-time teachers are usually the heads of departments within the polytechnic. During their 1-day of teaching, they spend the morning coaching full-time teachers and in the afternoons are with the students. Other teachers return to the 
factory once a month or when the factory is not too busy. Some very experienced teachers who work 4 days in the factories also provide professional development training for the full-time teachers.

MoEC stipulates that teachers must have a master's degree; however, Astra Manufacturing Polytechnic considers it more important that teachers have industry experience and are competent in the areas they are teaching. This demonstrates that the polytechnic understands the value of TVET; that is, practical skills are recognized to be as valuable as other skills, depending on the context. The value of being competent in a technical area is an essential base for teaching technical skills. The polytechnic analyzes the training needs of its teachers and can then bring technical specialists from the factories to develop the teachers' skills. The polytechnic develops the pedagogical skills of their teachers and encourages student-centered learning, problem-based learning approaches, and competency development. It also sends the teachers to university to get a master's degree.

Previously, equipment would be updated every 9 years, but now they are upgraded within 5 years, along with some of the regulations associated with the equipment. This has an impact on the skills and knowledge of the full-time teachers. Their professional development and associated licenses are also costly to maintain. Environmental regulations change almost every year or two, which is where the workplace-based teachers are a very important link. They understand the changes that are implemented and introduce them into the Astra Manufacturing Polytechnic programs.

The different divisions within Astra International provide detail on the competency standards that students are required to achieve. The competency standards are aligned to job opportunities within the Astra Group of companies. Astra Manufacturing Polytechnic then develops the curriculum to match competency standards, embedding basic knowledge such as the compulsory subjects of Bahasa Indonesia, religion, and English and during the final year incorporating generic skills and green skills (such as waste management and energy and water efficiency). The teachers all have workplace experience of varying degrees, updated regularly to ensure that workplace best practice approaches are incorporated into workshop training.

Students first visit the factories before they start their first semester of training to observe what is happening in the workplace. A teacher visits with them and explains what they are observing. The students continue to visit the factories for observations every semester. During these visits, they are encouraged through prompts to consider back in the workshops and classrooms what they have learned. The method in the first year is to observe particular approaches. In the second year, the students must be able to identify various aspects of the work, such as the processes that lead to cleaner production and zero waste or lead to environmental compliance. In the final year, they work to apply their technical, process, and soft skills in the workplace.

The model in Fig. 1, developed by Astra Manufacturing Polytechnic, presents the various aspects of competency that make up the curriculum, and the relationship between the polytechnic and the Astra Group of industries. Many training 


\section{Competence Development Model}
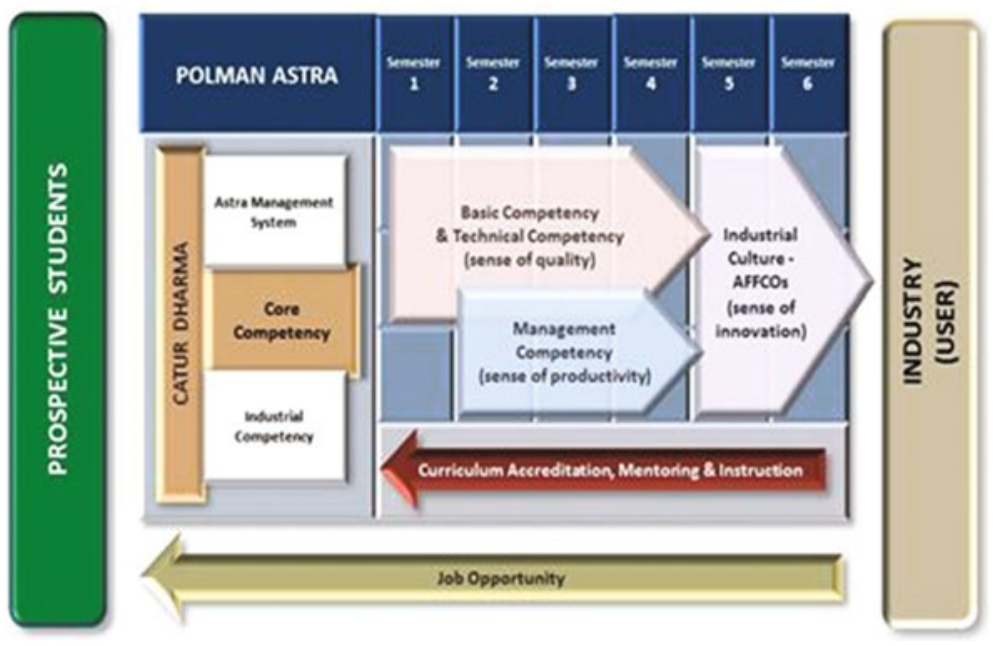

Fig. 1 Astra Manufacturing Polytechnic, 2013.

institutions in the Asia and Pacific region focus on a narrow range of technical skills development (Martinez-Fernandez and Powell 2009). Regionally, there is a recognized lack of soft skills and workplace process skills. Students may learn to weld two sheets of metal together but are not required to consider timelines, quality standards, or cost issues. In the Astra Manufacturing Polytechnic courses, programs are made up of $65 \%$ practical skills development and $35 \%$ theory.

The seven programs conducted at Astra Manufacturing Polytechnic are mechanical engineering and tool manufacturing, production process, mill, mechatronics, four wheelers, heavy equipment, and information management. These programs constitute the core competencies identified in Fig. 1 and are offered to meet an identified demand from within the different divisions in the Astra Group. The management competencies identified in Fig. 1 covers the Astra quality management system and include quality improvement. The industrial competency component represents the workplace internship. It is also a mandatory government requirement for polytechnics to teach religion, civics, and state ideology, which represent $1 \%$ of the curriculum. During the first year, students learn basic and technical competencies and develop a sense of quality through the processes of assimilating technical competencies within their workplace observations. From the second year, the program offers management competencies to develop a sense of productivity. Building on the technical skills developed in the first year, the second year leads to the accommodation of new learning (Piaget 1978) around the interplay of technical skills and productivity. In the final year, developing innovation skills is emphasized. Students undertake a 6-9 month internship or apprenticeship with one of the Astra affiliate companies as part of the learning process. This structure of 
learning is not only informed by pedagogical considerations, but also by the formalities of the workplace, where there is no room for less skilled workers attempting process changes or innovations until they have developed these skills.

The students are assigned a mentor who will teach the best practices in the workplace, including environmental compliance, and ensure that they are given exposure to a number of areas to develop general skills. The mentor will also help the students to devise an idea for their projects. Astra International encourages its staff to participate in "kaizen" (continuous improvement) through quality control circles. Staff members are divided into several circles (groups) and every year have to create an improvement process in their area. The ideas for the final project originate from a list of areas that are developed by these groups, including reducing environmental impact, improving production efficiency, and improving quality. Once students have started an internship or apprenticeship, they then choose two areas of interest. The quality control circles identify which aspect of one of these areas a student should explore. The company assigns an additional mentor if needed, who could be from outside the factory or an international person, to advise, support, and improve the project.

When the student completes the final project, the teacher and workplace mentor assess the project. If there is an external mentor, that person is also involved in the project assessment. Workplace learning is different from classroom and workshop learning in a number of fundamental respects. For example, workplace learning is usually focused on behavior, and workshop learning is usually focused on cognitive processes and the formation of skills. The aim of the internships is for students to apply their newly acquired skills and tools in authentic workplace environments, applying theory to their practice. Furthermore, students develop their technical skills within workplace processes and at the same time are complying with procedures and deadlines while cultivating the company culture. Opportunities are also provided for the factories to select and recruit candidates.

A final project must be completed by all students. It is not a theory-based project, but a practical quality improvement project. The aim is to develop innovation skills and reinforce skills in problem solving and continuous improvement. An example of a final improvement project is one in which a student worked to control air pollution in the automotive workshop by developing a pollutant reduction device. Another example involved improving the control system on a snap ring checker machine, which resulted in a decrease in the lead time and a reduction in the number of people required to undertake the task.

While mentors do not have formal training skills, the teachers engage with the mentors and monitor the students in the workplace at least once every 10 days or 2 weeks. This provides a formal structure to workplace learning, as they discuss student progress with the student and mentor, identifying any problems and discussing coping strategies. The teachers also review progress on the design of their final projects. There is a strong connection among the teachers, students, and mentors in the industry, providing a structure and creating a formal process for the workplace learning component. The company factories would like more interns; however, the polytechnic cannot meet their requirements, as they have a small student body. 
The Astra Manufacturing Polytechnic model of integration for on- and off-the-job training is a sophisticated good-practice model. While the polytechnic has the advantage of being owned by the company, where students eventually find employment, useful insights are offered for all TVET training institutions on good workplace and institutional integration arrangements. The workplace training component is inherently pedagogical (Billett 2004), as students move from structured workplace observations of experienced practitioners at the commencement and in the early stages in the course, to learning as participatory practice (Billett 2004) in the latter part of the course. The course structure, as a whole, is intentionally sequenced to make the most of the complementary learning opportunities offered in the workplace and institutional context.

What is found in the Astra Manufacturing Polytechnic model is that the workplace component is not treated as a separate adjunct to the learning process, but rather that learning and participation in work are inseparable (Billett 2004). The success of this approach is indicated by the high number $(69 \%)$ of graduates who are immediately productive (work-ready).

\section{Meister Program for Existing Workers}

Hager (1997) notes that one of the major impacts on the quality of learning that occurs in a workplace is the workplace environment or culture. The polytechnic has established a special 1-year Meister Program for existing workers, with entry requirements very different from other programs. Potential students must have high technical skills and up to 4 years of work experience. This entry requirement falls outside the guidelines of the Indonesian Qualifications Framework, which is not flexible enough to allow entry requirements of experience only. It is very difficult under current government regulations to recognize prior learning, so the solution is the Meister Program, which is accredited by Astra. The Astra Group of companies has many highly skilled workers who have learned their skills informally but cannot gain formal recognition, which this course provides. The polytechnic enrolls workers in the D III who have experience, but under current national arrangements cannot be given advanced recognition for skills and knowledge gained on the job. They can give concessions in some subjects to the experts, and so the Meister Program examines the skills of the workers against industry standards. If the standards are met, they will be given Meister recognition. While the program is not recognized by the formal TVET system in Indonesia, it is recognized by industry, as Astra is considered to have high standards. Workers, therefore, have a credible qualification should they change employment.

The polytechnic also conducts short courses for Astra workers that are open to the public, but mostly filled from within the Astra Group due to demand. These programs, combined with the company's commitment to the polytechnic, suggest that Astra International places a high value on education and training, which, in turn, reinforces the quality of learning that occurs in the workplace (Fig. 2).

At the time of placement, $69 \%$ of students are usually already able to meet the needs of Astra and contribute productively to the workplace. Students receive their certificates once they have finished all assessments and the apprenticeship. Some 


\section{Polman Astra within Astra Supply Chain}

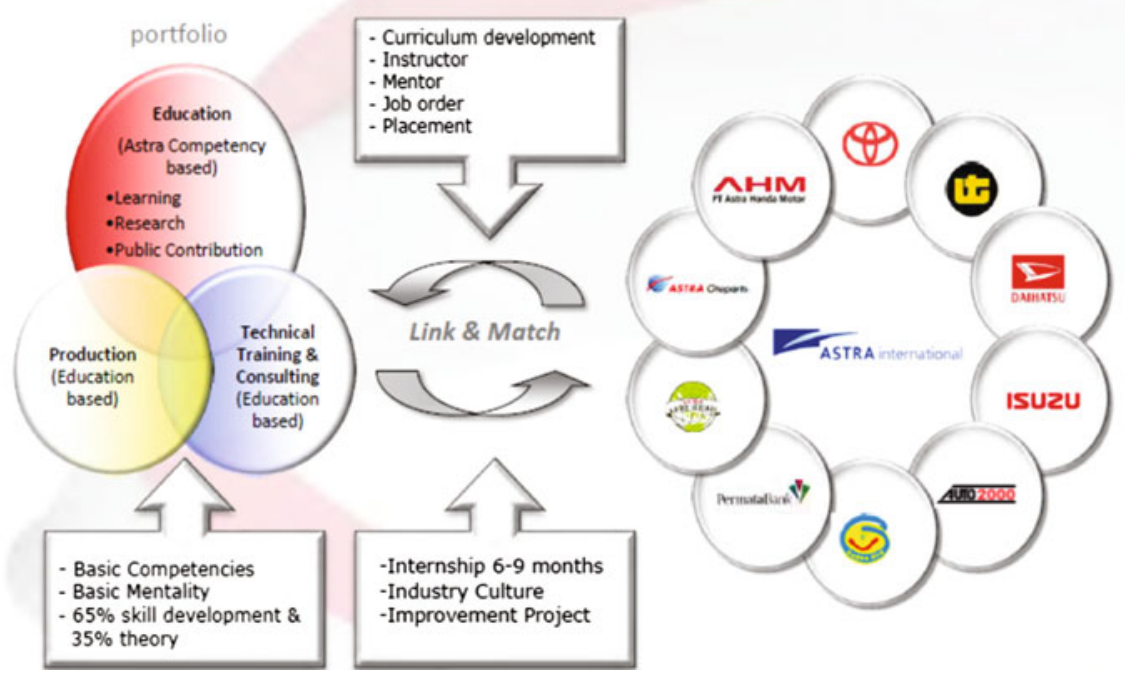

Fig. 2 Indonesia VET, 2012.

assessments occur in the workplace, particularly the final project. All assessments involve the teacher and the workplace mentor undertaking the assessment together, emphasizing the value of workers' expertise and their knowledge of applying technical skills to meet workplace standards.

Emphasizing the success of the polytechnic, several companies have visited Astra Manufacturing Polytechnic with a view to establishing their own polytechnics.

The Astra Group provides automotive technical manuals to technical vocational high schools throughout Indonesia. Assistance in the form of teaching and learning aids, including automobiles and transmissions, are also provided by the group.

Students from these VSSs are recruited onto Astra Manufacturing Polytechnic courses and receive a full scholarship to attend, which covers tuition and a small living allowance. Astra Manufacturing Polytechnic hopes that by improving the skills of students graduating from VSSs and entering the polytechnic, the overall standard of the polytechnic's graduates will also be higher.

\section{$5 \quad$ Key Learning}

All relevant environmental regulations, both national and international, are incorporated into Astra Manufacturing Polytechnic training programs and internships.

There is no special program for green skills, but each subject has an integrated approach to green skills. As the students learn a set of technical skills, they are also learning to comply with environmental regulations and standards, along with Astra Groups' green policies. Green skills are incorporated across subjects in the 
curriculum, with areas such as energy efficiency, waste reduction, liquid and solid waste management and disposal, recycling, water efficiency, and reduction of chemical usage covered under the relevant areas in the training programs.

In summary:

- First-year students learn basic competencies and technical competencies and develop a sense of quality through the processes of assimilating technical competencies with workplace observations.

- The second-year program offers management competencies to develop a sense of productivity; building on the technical skills developed in the first year, the second year leads to the accommodation of new learning (Piaget 1978) around the interplay of technical skills and productivity.

- In the final year, developing innovation skills is emphasized. Final-year students undertake a 6-9 month internship or apprenticeship with one of the Astra affiliate companies as part of the learning process.

In the Astra Manufacturing Polytechnic model the workplace component is not treated as a separate adjunct to the learning process. Instead, learning through participation in work is inseparable from classroom and workshop training. The success of this approach is indicated by the high number $(69 \%)$ of graduates who are immediately productive (work-ready).

Astra International places a high value on education and training, which, in turn, reinforces the quality of learning that occurs in the workplace.

The views expressed in this publication are those of the authors and do not necessarily reflect the views and policies of the Asian Development Bank (ADB) or its Board of Governors or the governments they represent.

ADB does not guarantee the accuracy of the data included in this publication and accepts no responsibility for any consequence of their use. The mention of specific companies or products of manufacturers does not imply that they are endorsed or recommended by ADB in preference to others of a similar nature that are not mentioned.

By making any designation of or reference to a particular territory or geographic area, or by using the term "country" in this document, ADB does not intend to make any judgments as to the legal or other status of any territory or area.

Open Access This work is available under the Creative Commons Attribution 3.0 IGO license (CC BY 3.0 IGO) https://creativecommons.org/licenses/by/3.0/igo/. By using the content of this publication, you agree to be bound by the terms of this license. For attribution, translations, adaptations, and permissions, please read the provisions and terms of use at https://www.adb.org/ terms-use\#openaccess This CC license does not apply to non-ADB copyright materials in this publication. If the material is attributed to another source, please contact the copyright owner or publisher of that source for permission to reproduce it. ADB cannot be held liable for any claims that arise as a result of your use of the material.

Please contact pubsmarketing@adb.org if you have questions or comments with respect to content, or if you wish to obtain copyright permission for your intended use that does not fall within these terms, or for permission to use the ADB logo.

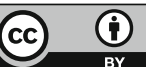

